\title{
Radiolytic Preparation of Electrocatalysts with Pt-Co and Pt-Sn Nanoparticles for a Proton Exchange Membrane Fuel Cell
}

\author{
Sang Kyum Kim, ${ }^{1}$ Ji Yun Park, ${ }^{2}$ Soon Choel Hwang, ${ }^{1}$ Do Kyun Lee, ${ }^{2}$ Sang Heon Lee, \\ Moon Hee Han, ${ }^{1}$ and Young Woo Rhee ${ }^{1}$ \\ ${ }^{1}$ Graduate School of Energy Science and Technology, Chungnam National University, 99 Daehak-ro, Yusung-gu, \\ Daejeon 305-764, Republic of Korea \\ ${ }^{2}$ Department of Applied Chemistry and Biological Engineering, Chungnam National University, Daejeon 305-764, Republic of Korea
}

Correspondence should be addressed to Young Woo Rhee; ywrhee@cnu.ac.kr

Received 30 December 2013; Accepted 10 April 2014; Published 4 May 2014

Academic Editor: Ajay Soni

Copyright (C) 2014 Sang Kyum Kim et al. This is an open access article distributed under the Creative Commons Attribution License, which permits unrestricted use, distribution, and reproduction in any medium, provided the original work is properly cited.

\begin{abstract}
Nanosized Pt-Sn/VC and Pt-Co/VC electrocatalysts were prepared by a one-step radiation-induced reduction (30 kGy) process using distilled water as the solvent and Vulcan XC72 as the supporting material. While the Pt-Co/VC electrodes were compared with $\mathrm{Pt} / \mathrm{VC}$ ( $40 \mathrm{wt} \%$, HiSpec 4000), in terms of their electrocatalytic activity towards the oxidation of $\mathrm{H}_{2}$, the Pt-Co/VC electrodes were evaluated in terms of their activity towards the hydrogen oxidation reaction (HOR) and compared with $\mathrm{Pt} / \mathrm{VC}(40 \mathrm{wt} \%$, HiSpec 4000), Pt-Co/VC, and Pt-Sn/VC in a single cell. Additionally, the prepared electrocatalyst samples (Pt-Co/VC and Pt$\mathrm{Sn} / \mathrm{VC}$ ) were characterized by transmission electron microscopy (TEM), scanning electron microscope (SEM), thermogravimetric analysis (TGA), X-ray diffraction (XRD), X-ray photoelectron spectroscopy (XPS), electrochemical surface area (ECSA), and fuel cell polarization performance.
\end{abstract}

\section{Introduction}

Fuel cells have garnered global attention in recent decades due to their high efficiency and environmental compatibility $[1,2]$. Among various types of fuel cells, proton exchange membrane fuel cells (PEMFC) have shown great promise as an alternative source of power generation for transportation applications due to their low operating temperature, fast startup, high power density, and low emission of pollutants [1-5]. However, to make PEMFCs commercially viable, some technical and economical challenges have to be overcome, including the poor kinetics of the anodic reaction, the complicated catalyst loading process, and the high cost of electrocatalysts [6-9].

In a standard $\mathrm{H}_{2}$ fuel cell, the PEMFC anode catalyst facilitates the following hydrogen oxidation reaction (HOR):

$$
\mathrm{H}_{2} \longrightarrow 2 \mathrm{H}^{+}+2 \mathrm{e}^{-}
$$

Currently, the best electrocatalyst for the HOR is platinum $(\mathrm{Pt})$. The extremely high activity of $\mathrm{Pt}$ is believed to be due to the nearly optimal bonding affinity that exists between $\mathrm{Pt}$ and hydrogen. The bonding is strong enough to promote facile absorption of $\mathrm{H}_{2}$ from the gas phase onto a Pt surface and the subsequent electron transfer, but the bonding is weak enough to allow desorption of the resultant $\mathrm{H}^{+}$ion into the electrolyte [10-14]. In contrast, the bond between $\mathrm{H}_{2}$ and metals like $\mathrm{W}, \mathrm{Mo}, \mathrm{Nb}$, and $\mathrm{Ta}$ is too strong, resulting in a stable hydride phase. On the other hand, the bond between $\mathrm{H}_{2}$ and metals like $\mathrm{Co}, \mathrm{Pb}, \mathrm{Sn}, \mathrm{Zn}, \mathrm{Ag}, \mathrm{Cu}$, and $\mathrm{Au}$ is too weak, resulting in little or no absorption [15-21].

Although Pt is expensive, it proves to be an exceptionally effective catalyst for the HOR. Using the well-developed $\mathrm{Pt} / \mathrm{VC}$ catalyst approach, whereby ultrasmall $(2-3 \mathrm{~nm}) \mathrm{Pt}$ particles are supported on a high-surface-area carbon powder, only an extremely small amount of Pt catalyst is required. Thus, typical Pt loadings in PEMFC anodes have been successfully reduced to around $0.05 \mathrm{mg} \mathrm{Pt} / \mathrm{cm}^{2}$. At these levels, the anode Pt catalyst expense is relatively modest compared to the expense associated with other components in the fuel cell. For example, a $50 \mathrm{~kW}$ automotive fuel cell stack, 
operating at a power density of $1.0 \mathrm{~W} / \mathrm{cm}^{2}$, would require about 2.5 grams of $\mathrm{Pt}$ for the anode catalyst. At a price of $\$ 42 / \mathrm{g}$, this represents a Pt material cost of approximately $\$ 100$ $[1-3,14,16]$.

In this study, we prepared the Pt-Co/VC (Vulcan XC72) and $\mathrm{Pt}-\mathrm{Sn} / \mathrm{VC}$ electrocatalysts by one-step radiation-induced reduction. The obtained electrocatalysts have overcome the disadvantages of the PEMFC (e.g., high cost and a weak bond with $\mathrm{H}_{2}$ ). Pt-Co/VC and Pt-Sn/VC electrocatalysts were then characterized by transmission electron microscopy (TEM), scanning electron microscope-energy dispersive spectroscopic (SEM-EDS), thermogravimetric analysis (TGA), Xray diffraction (XRD), X-ray photoelectron spectroscopy (XPS), electrochemical surface area (ECSA), and fuel cell polarization performance $[17,18]$.

\section{Experimental}

2.1. Chemicals. In this experiment, the $\mathrm{H}_{2} \mathrm{PtCl}_{6} \cdot \mathrm{H}_{2} \mathrm{O}(37.5 \%$ $\mathrm{Pt}), \mathrm{CoCl}_{2} \cdot \mathrm{H}_{2} \mathrm{O}(47.4 \% \mathrm{Co})$, and $\mathrm{SnCl}_{2} \cdot \mathrm{H}_{2} \mathrm{O}(52.0 \% \mathrm{Sn})$ were of analytical reagent grade (Sigma-Aldrich, USA) and were used without further purification. Carbon black (Vulcan XC72) was purchased from CABOT Co., Ltd. (USA). Nafion (perfluorinated ion-exchange resin, 5\% (w/v) solution in a solution of $90 \%$ aliphatic alcohol/10\% water mixture) was also purchased from Sigma-Aldrich (USA). Solutions for the experiments were prepared with water purified in an aquaMAX-Basic 360 series plus water purification system (YL Instruments Co., Ltd., Korea). The final resistance of the water was $18.2 \mathrm{M} \Omega \mathrm{cm}^{-1}$ and the solutions were degassed prior to each measurement. The other chemicals used in the experiment were of reagent grade.

2.2. One-Step Preparation of Electrocatalysts by RadiationInduced Reduction. First, VC (Vulcan XC72) was purified to remove the noncrystallized carbon impurities. VC was treated with a mixture of $\mathrm{H}_{2} \mathrm{SO}_{4} / \mathrm{H}_{2} \mathrm{O}(2: 8 \mathrm{vol} \%)$ and, in the process, VC was purified. The purified VC was used as the supporting material for deposition of the catalysts. The Pt-Co/VC catalyst was prepared as follows: $\mathrm{H}_{2} \mathrm{PtCl}_{6} \cdot \mathrm{H}_{2} \mathrm{O}$ $(0.43 \mathrm{~g})$ and $\mathrm{CoCl}_{2} \cdot \mathrm{H}_{2} \mathrm{O}(0.37 \mathrm{~g})$ were dissolved in a mixture of deionized water $(188 \mathrm{~mL})$ and 2-propanol $(12.0 \mathrm{~mL})$ was added as a radical scavenger. Next, $1.0 \mathrm{~g}$ of the purified VC support was added to the previously mentioned solution. The $\mathrm{PH}$ of the reaction solution was adjusted to 10.0 using $\mathrm{NaOH}$. Nitrogen was bubbled through the solution for $30 \mathrm{~min}$ to remove oxygen and then the solution was irradiated under atmospheric pressure and ambient temperature. A total irradiation dose of $30 \mathrm{kGy}$ (dose rate $=6.48 \times 10^{5} / \mathrm{h}$ ) was applied. Pt-Co nanoparticle-deposited VC catalysts were precipitated after $\gamma$-irradiation. The $\mathrm{Pt}-\mathrm{Sn} / \mathrm{VC}$ electrocatalysts were prepared as described above. The molar ratios of the input metal ions are $\mathrm{Pt}-\mathrm{Co} / \mathrm{VC}(\mathrm{Pt} / \mathrm{Co}=0.6 / 0.4)$ and $\mathrm{Pt}-$ $\mathrm{Sn} / \mathrm{VC}(\mathrm{Pt} / \mathrm{Sn}=0.6 / 0.4)$.

2.3. Characterization of Electrocatalysts Surface. The particle size and morphology of the electrocatalysts were analyzed by SEM-EDS images obtained with a Hitachi S-4800 microscope operated at $30 \mathrm{kV}$. The HR-TEM images were obtained using a JEOL JEM-2100 microscope operated at $200 \mathrm{kV}$. The TGA of the PEM was made on the TA instruments of the TGA S-1000 model with a heating rate of $10^{\circ} \mathrm{C} / \mathrm{min}$, in a temperature range of $0-800^{\circ} \mathrm{C}$. XRD was conducted using a Japanese Rigaku $\mathrm{D} / \max \gamma \mathrm{A}$ XRD, equipped with graphite monochromatized $\mathrm{Cu} \mathrm{K} \alpha$ radiation $(\lambda=0.15414 \mathrm{~nm})$. The XPS analyses were carried out with a MultiLab 2000 (Thermo) XPS using a monochromated $\mathrm{Al} \mathrm{Ka}$ source under a base pressure of $2.6 \times$ $10^{-9}$ torr.

\subsection{Characterization of Electrochemical Performance Mea-} surement. Electrochemical measurements were carried out at room temperature in a three-electrode cell connected to an electrochemical analysis. A glassy carbon, coated with a catalyst, was used as the working electrode. An $\mathrm{Ag} / \mathrm{AgCl}$ electrode and a Pt electrode were used as a reference electrode and as a counter electrode, respectively. Unless otherwise stated, all potentials were relative to the $\mathrm{Ag} / \mathrm{AgCl}$. HOR activity tests can be conducted by cyclic voltammogram $(\mathrm{CV})$. With the $\mathrm{CV}$, the $\mathrm{HOR}$ was measured in oxygensaturated $0.5 \mathrm{M} \mathrm{H}_{2} \mathrm{SO}_{4}$ at $25^{\circ} \mathrm{C}$ with the scan rate of $0.1 \mathrm{~V} \mathrm{~s}^{-1}$, in the potential ranging from $-0.2 \mathrm{~V}$ to $+0.3 \mathrm{~V}$.

Single cells were constructed to evaluate the fuel cell polarization performance of the Pt-Co and Pt-Sn catalyst electrodes. Membrane electrode assembly (MEA), with an area of $10 \mathrm{~cm}^{2}$, was used to construct a single cell, which had been fabricated by hot-pressing a pretreated Nafion 112 membrane (DuPont) between the anode and the cathode. The catalyst loadings were $0.2 \mathrm{mg}$ of $\mathrm{Pt}$ at the cathode and $0.4 \mathrm{mg}$ of Pt-Co, Pt-Sn at the anode. For all the tests, Pt (40 wt\%)/VC (HiSpec 4000) was used as the anode catalyst. The catalyst inks were prepared in a mixture solution composed of an appropriate amount of DI water and the required amount of $5 \mathrm{wt} \%$ Nafion ionomer solution (Aldrich). The Nafion ionomer content was $20 \mathrm{wt} \%$ in the anode catalyst layer and $25 \mathrm{wt} \%$ in the cathode catalyst layer. The appropriate amount of catalyst inks was painted uniformly on Teflon-coated carbon paper (TGPH-090) and dried at $80^{\circ} \mathrm{C}$ overnight. Fuel cell polarization performance tests were conducted at $60^{\circ} \mathrm{C}$ with a WFCTS fuel cell test station.

\section{Results and Discussion}

Pt-M/VC catalysts were successfully prepared by a one-step radiation-induced reduction (RIR) process. Diverse papers have reported that the mechanism of RIR could be generally proven by the following equation [22-28]:

$$
\mathrm{H}_{2} \mathrm{O} \longrightarrow \mathrm{e}_{\mathrm{aq}}{ }^{-}, \mathrm{H}^{+}, \mathrm{H}^{\bullet}, \mathrm{OH}^{\bullet}, \mathrm{H}_{2}, \mathrm{H}_{2} \mathrm{O}_{2}
$$

Among these, free radical $\left(\mathrm{H}^{\bullet}\right)$ and solvated electrons $\left(\mathrm{e}_{\mathrm{aq}}{ }^{-}\right)$were used as strong reducing agents to reduce the metal ions up to the zero-valence state, as shown in

$$
\begin{gathered}
\mathrm{M}^{+}+\mathrm{e}_{\mathrm{aq}}^{-} \longrightarrow \mathrm{M}^{0}, \\
\mathrm{M}^{+}+\mathrm{H}^{\bullet} \longrightarrow \mathrm{M}^{0}+\mathrm{H}^{+}
\end{gathered}
$$



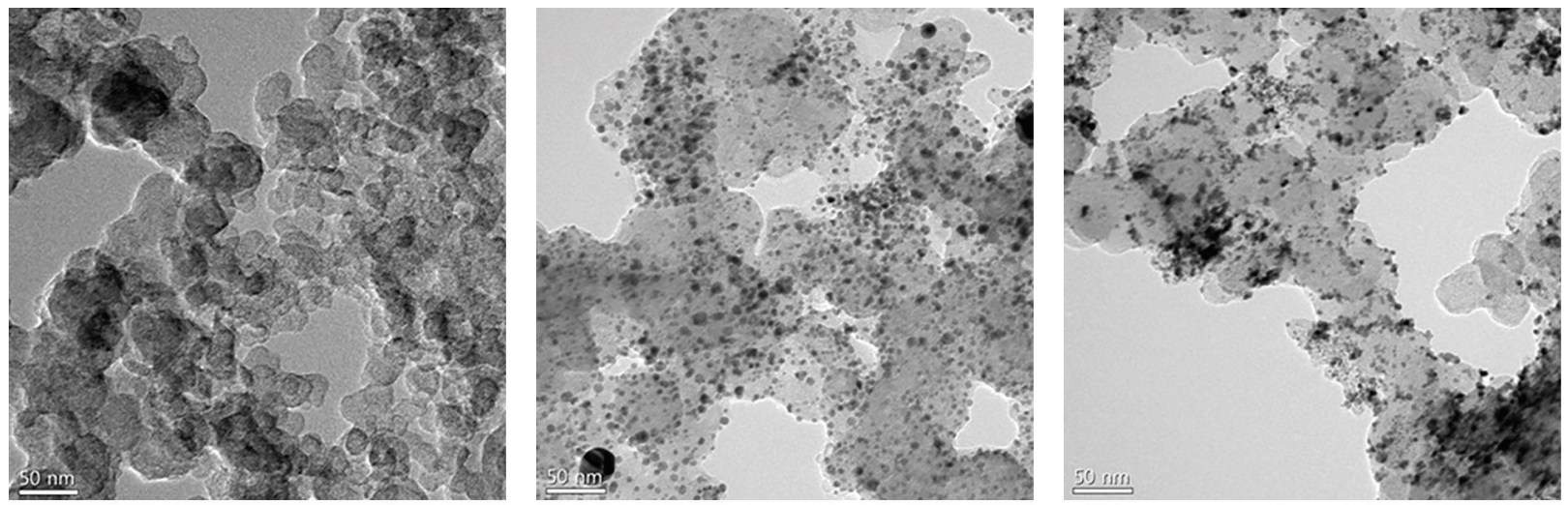

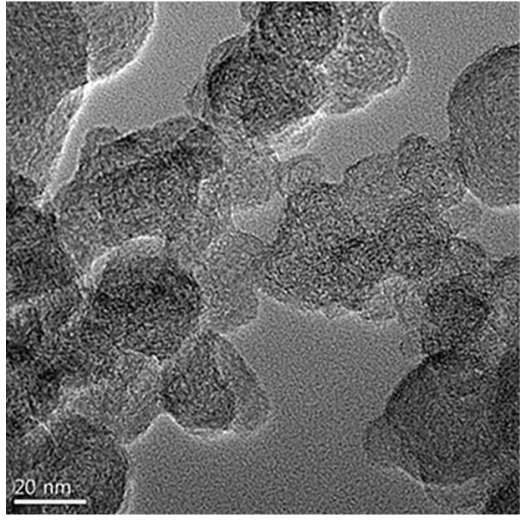

(a)

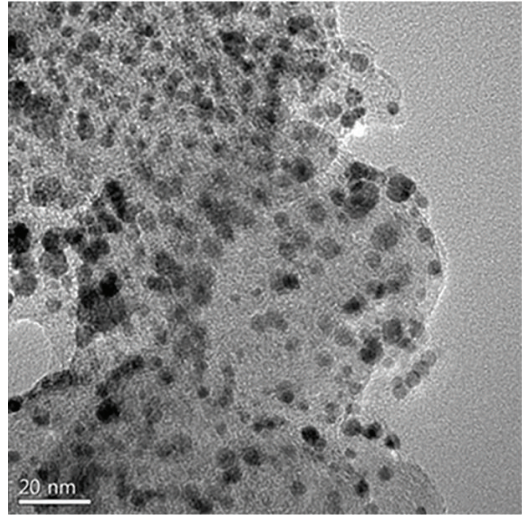

(b)

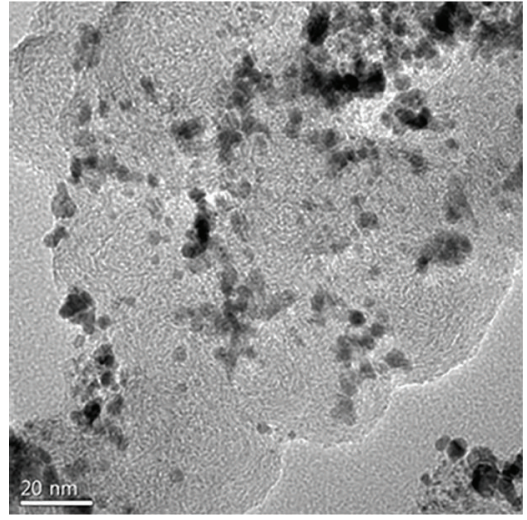

(c)

FIgure 1: TEM image of original VC (a), Pt-Co/VC (b), and Pt-Sn/VC (c) prepared by RIR.

Similarly, multivalent ions, such as $\mathrm{Pt}^{4+}, \mathrm{Co}^{2+}$, and $\mathrm{Sn}^{2+}$, are reduced by a multistep reaction. On the other hand, the hydroxyl radical $\left(\mathrm{OH}^{*}\right)$ has a high oxidizing capacity and metal atoms and ions can be oxidized by hydroxyl radical. In order to protect the oxidizing agent $\left(\mathrm{OH}^{*}\right), 2$-propanol was added to the reaction solution. The $\mathrm{OH}^{*}$ radical reacted with 2-propanol, as shown in (5). As a result, the metal ion was then reduced to a zero-valence metal atom by 2 -propanol radical, as shown in (6):

$$
\begin{gathered}
\left(\mathrm{CH}_{3}\right)_{2} \mathrm{CHOH}+{ }^{\bullet} \mathrm{OH} \longrightarrow\left(\mathrm{CH}_{3}\right)_{2} \mathrm{C}^{\bullet} \mathrm{OH}+\mathrm{H}_{2} \mathrm{O}, \\
\mathrm{M}^{+}+\left(\mathrm{CH}_{3}\right)_{2} \mathrm{C}^{\bullet} \mathrm{OH} \longrightarrow \mathrm{M}^{0}+\left(\mathrm{CH}_{3}\right)_{2} \mathrm{C}=\mathrm{O}+\mathrm{H}^{+}
\end{gathered}
$$

Similar to the findings of Choi et al. [24, 26, 28], various metal and vinyl monomers were grafted onto the surface of MWNT via trapped radicals. The results showed that RIR was an effective metal deposition method on the surface of the VC-supported electrocatalysts.

Figure 1 shows the HR-TEM images of the VC-supported electrocatalysts prepared by one-step radiation reaction. They are (a) purified VC, (b) Pt-Co/VC, and (c) Pt-Sn/VC catalysts, respectively. As shown in Figure 1(a), there are no metallic nanoparticles on the surface of the VC. Figures 1(b) and 1(c) show that the HR-TEM images of the Pt-M/VC $(\mathrm{M}=\mathrm{Co}$, $\mathrm{Sn}$ ) catalyst clearly provide evidence for more deposition of Pt-M alloy nanoparticles on the surface of VC composites compared to the surface of pristine VC. The mean particle size of the metallic nanoparticles was in $10 \mathrm{~nm}$ under.

Figure 2 shows SEM images of the VC-supported electrocatalysts prepared by one-step radiation reaction. They are (a) $\mathrm{Pt}-\mathrm{Co} / \mathrm{VC}$ and (b) Pt-Sn/VC catalysts, respectively. As shown in Figures 2(a) and 2(b), the SEM images of the Pt-M/VC catalyst clearly provide evidence for more deposition of Pt$\mathrm{M}$ alloy nanoparticles on the surface of the VC composites compared to the surface of the pristine VC. The mean particle size of the metallic nanoparticles were $10 \mathrm{~nm}$ under. This also indicates that the RIR is capable of preparing a stoichiometric Pt-M/VC electrocatalyst.

Although various strategies were used for synthesis of the Pt-Co/VC and Pt-Sn/VC catalysts, the TGA data shown in Figure 3 reveals that the actual metal loadings in all the $\mathrm{Pt}-\mathrm{Co} / \mathrm{VC}$ and $\mathrm{Pt}-\mathrm{Sn} / \mathrm{VC}$ electrocatalysts are very close to the normal value of 57 62 wt\%. This suggests that $\mathrm{Pt}-\mathrm{Co} / \mathrm{VC}$ and $\mathrm{Pt}-\mathrm{Sn} / \mathrm{VC}$ of the synthesis strategies are efficient for preparation of high metal loading Pt-M catalysts [29].

Figure 4 shows the XRD patterns for the $\mathrm{Pt}-\mathrm{Co} / \mathrm{VC}$ and $\mathrm{Pt}-\mathrm{Sn} / \mathrm{VC}$ electrocatalysts prepared by one-step radiationinduced reduction. The Pt-Co/VC and Pt-Sn/VC electrocatalysts exhibit characteristics of a Pt face-centered cubic (fcc) structure $[29,30]$. The average particle sizes were calculated using a Debye-Scherrer equation from the broadening of the Pt $(220)$ reflection $[27,28]$ as ca. $2.8 \mathrm{~nm}$ and $3.7 \mathrm{~nm}$ 

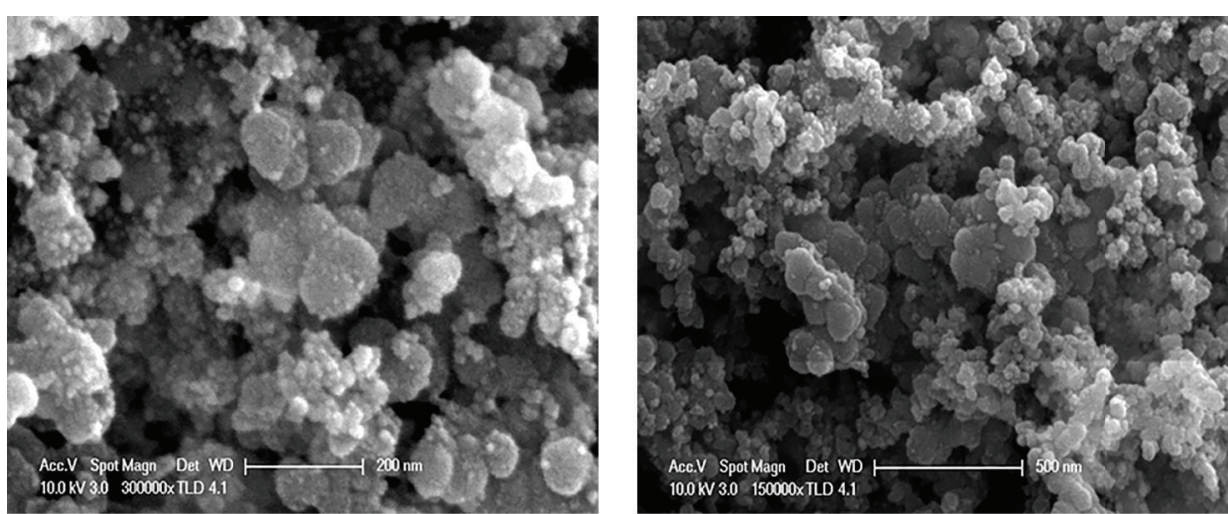

(a)
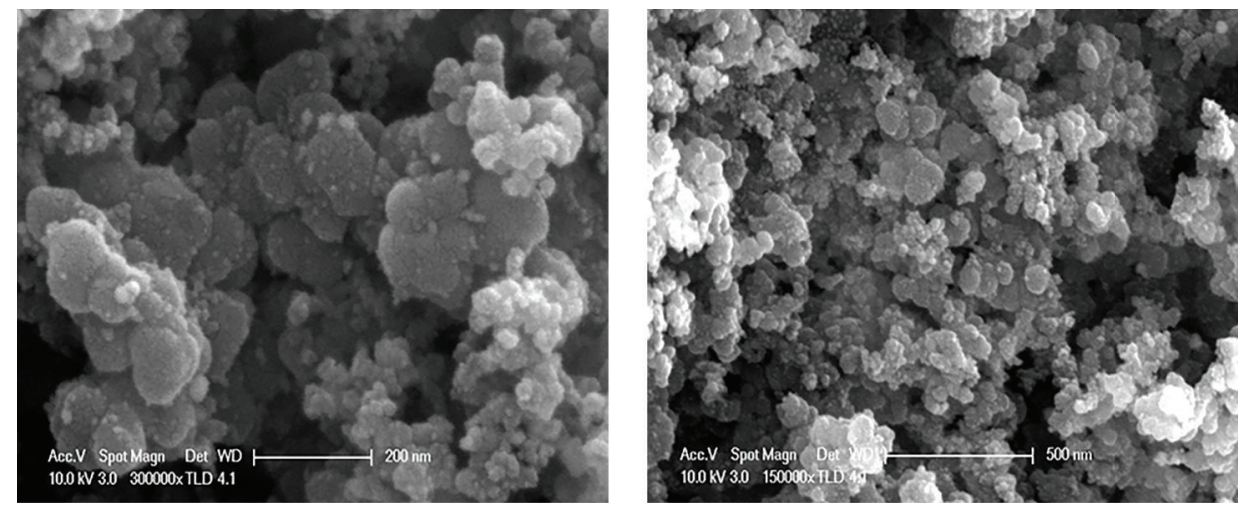

(b)

Figure 2: SEM images of the Pt-Co/VC and Pt-Sn/VC prepared by RIR.

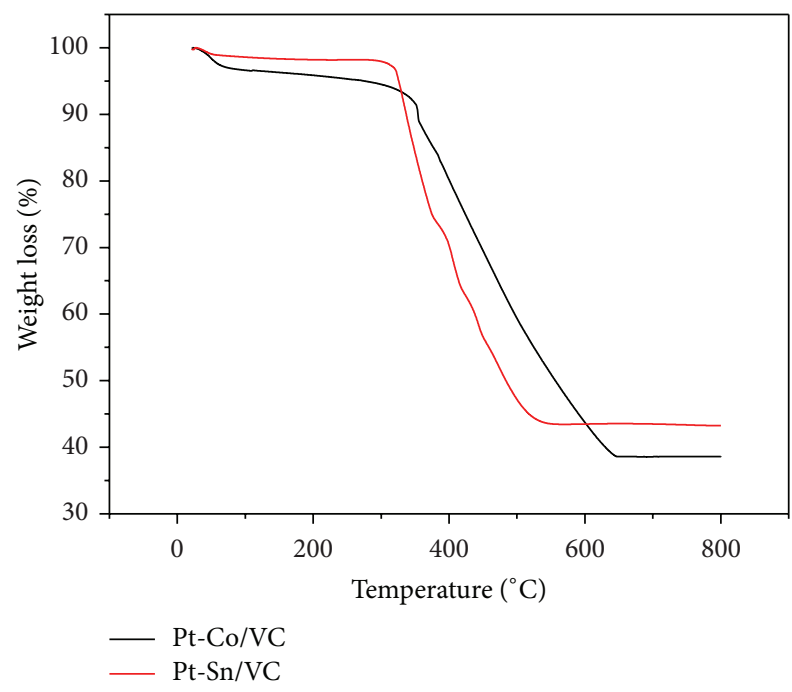

Figure 3: TGA data of Pt-Co/VC and Pt-Sn/VC by RIR.

for Pt-Co/VC and Pt-Sn/VC, respectively. The particle sizes calculated from the XRD data for Pt-Co nanoparticles are generally in good agreement with the randomly measured particle sizes from the HR-TEM and HR-SEM images shown in Figures 1 and 2.

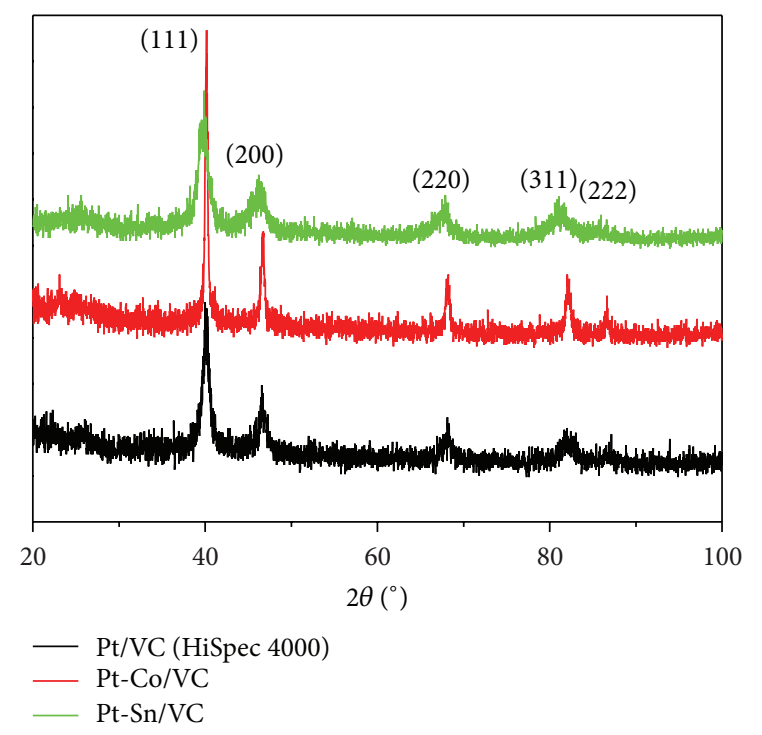

Figure 4: X-ray diffraction patterns of $\mathrm{Pt} / \mathrm{VC}, \mathrm{Pt}-\mathrm{Co} / \mathrm{VC}$, and PtSn/VC by RIR.

As shown in Figure 5, the XPS data was employed to analyze the valence state and the surface composition of the metal catalyst nanoparticles. Figures 5(b) shows the C1s, 


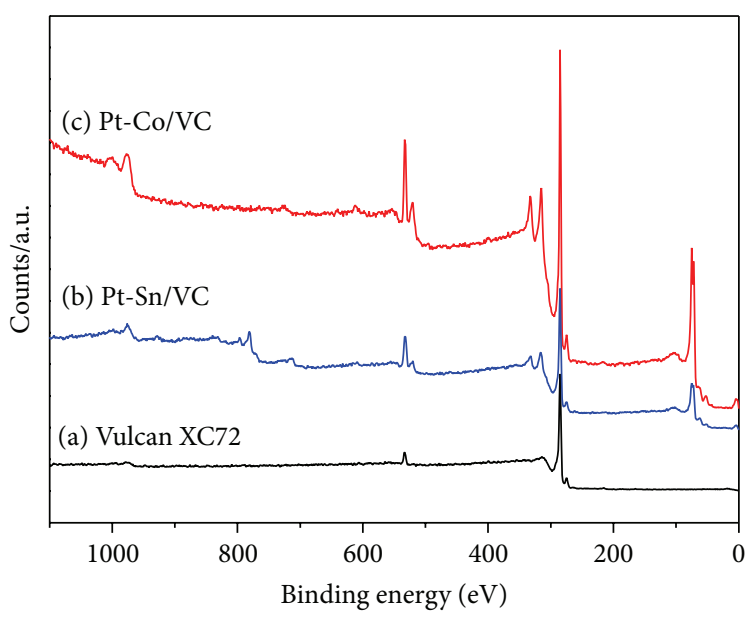

(a)
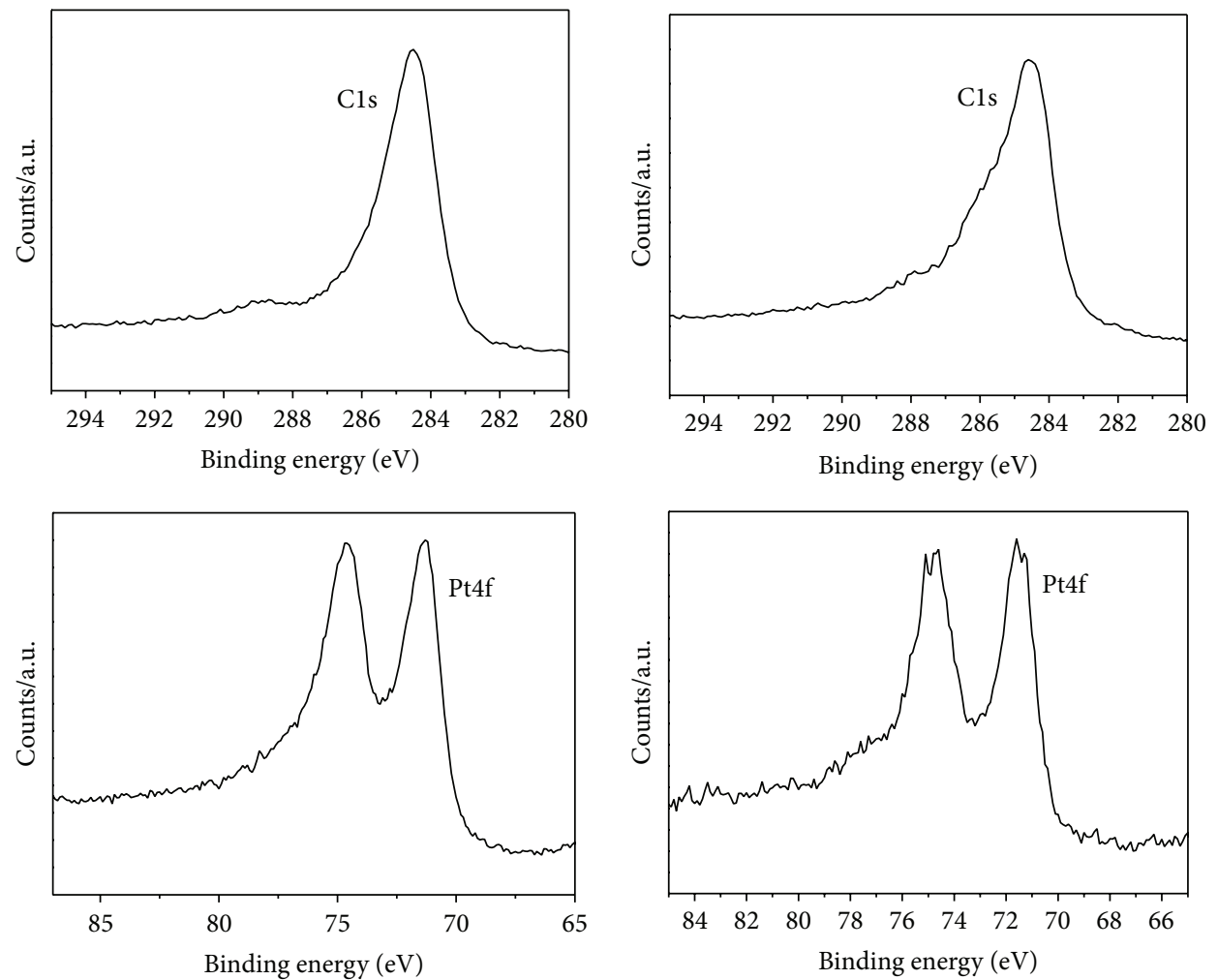

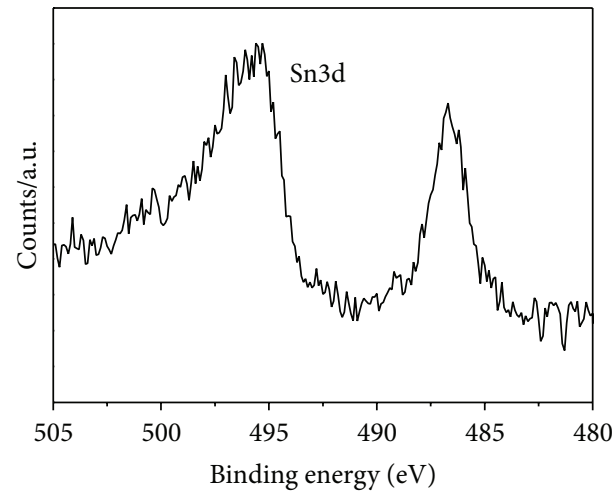

(b)

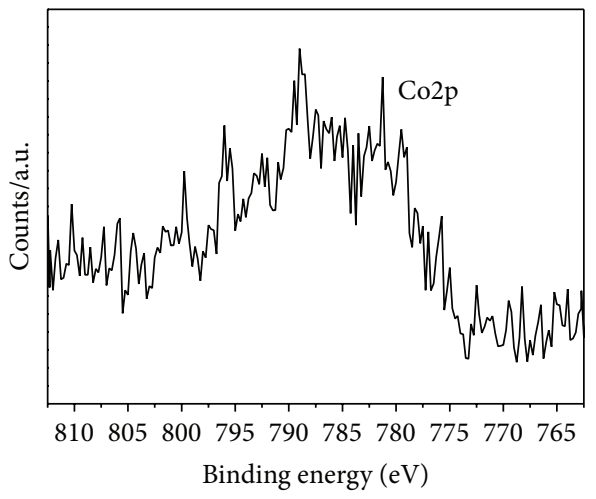

(c)

Figure 5: XPS spectra of original VC (a), Pt-Sn/VC (b), and Pt-CO/VC (c) by RIR. 


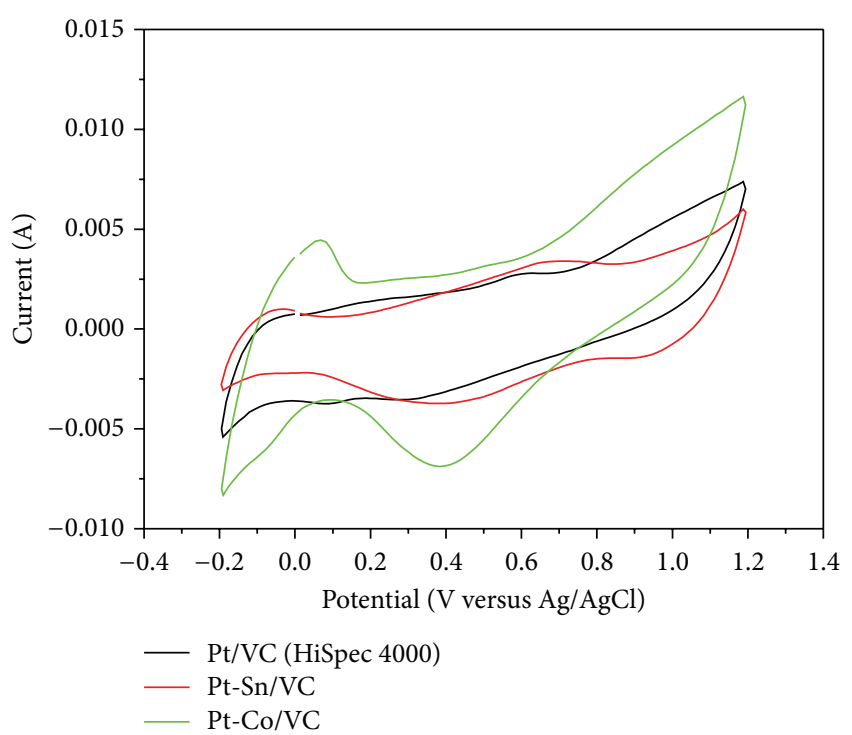

(a)

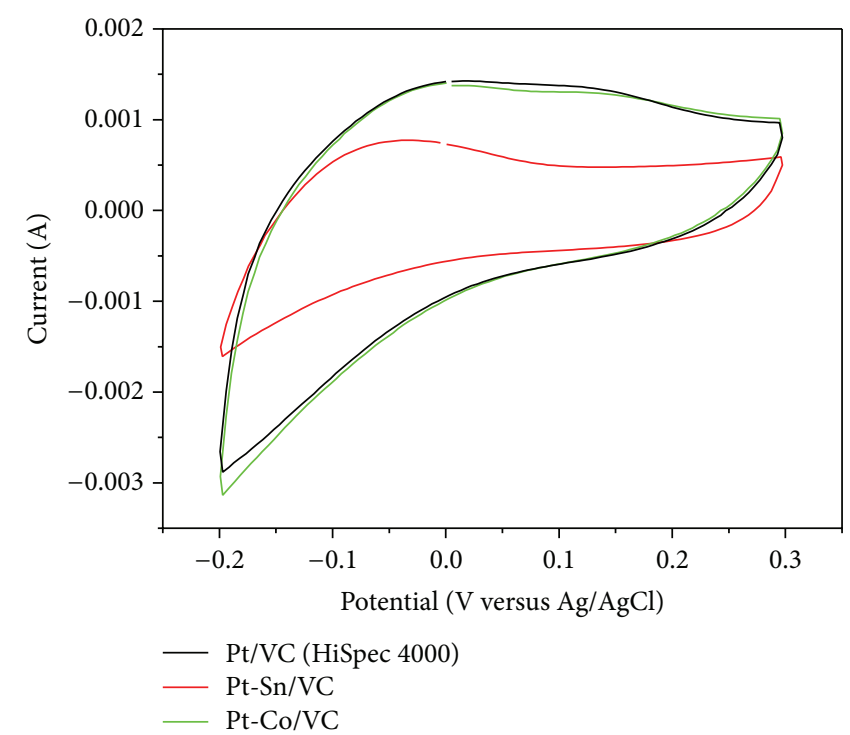

(b)

Figure 6: Cyclic voltammograms of the Pt-Co/C, Pt-Sn/VC, and Pt/VC (HiSpec 4000) electrodes in $0.5 \mathrm{M} \mathrm{H}_{2} \mathrm{SO}_{4}$; room temperature, scan rate $0.1 \mathrm{~V} / \mathrm{s}$.

Pt4f, and Sn3d peaks of the commercial Pt-Sn/VC catalysts prepared by RIR methods, respectively. The Cls peaks appear at $285 \mathrm{eV}$. The Pt4f peaks and Sn3d of the Pt-Sn/VC appear at $74,71 \mathrm{eV}$, and $496 \mathrm{eV}$ respectively. Figures 5(b) shows the C1s, $\mathrm{Pt} 4 \mathrm{f}$, and Co2P peaks of the commercial Pt-Sn/VC catalysts. The Pt4f peaks and the Co2p of the Pt-Co/VC appear at $74,71 \mathrm{eV}$, and $785 \mathrm{eV}$, respectively [31-33]. As a result, the Pt-Co and Pt-Sn were successfully deposited onto the VCsupported electrocatalyst by RIR.

Catalyst utilization efficiency is a very crucial factor which reflects the properties of catalysts, which is generally determined by dividing the electrochemical active surface area (ECSA) by the chemical surface area (CSA). Electrochemical surface area (ECSA) represents intrinsic electrocatalytic activity of electrocatalysts. The ECSA can be estimated from the integrated charge (after subtraction of capacitance contribution) in the hydrogen absorption region of the steady-state $\mathrm{CV}$ in $0.5 \mathrm{~mol} \mathrm{H}_{2} \mathrm{SO}_{4}$ under $\mathrm{N}_{2}$ atmosphere, based on a monolayer hydrogen adsorption charge of $0.2 \mathrm{mC} / \mathrm{cm}^{2}$ on crystalline Pt, Pt-Co, and Pt-Sn. Well-defined hydrogen adsorption/desorption characteristics were observed for Pt-M/VC electrocatalysts.

Figure 6 shows the cyclic voltammograms (CV) curves of the Pt/C (HiSpec 4000), Pt-Co/VC, and Pt-Sn/VC electrocatalysts in $0.5 \mathrm{M} \mathrm{H}_{2} \mathrm{SO}_{4}$ at room temperature under $\mathrm{N}_{2}$ atmosphere for the ECSA. The measured ECSA for the Pt$\mathrm{Co} / \mathrm{VC}$ was found to be $92 \mathrm{~m}^{2} \mathrm{~g}^{-1}$, which is much higher than the measured ECSA of Pt-Sn/VC and Pt/C (HiSpec 4000), which were $67 \mathrm{~m}^{2} \mathrm{~g}^{-1}$ and $72 \mathrm{~m}^{2} \mathrm{~g}^{-1}$, respectively. Compared with $\mathrm{Pt} / \mathrm{VC}$ and Pt-Sn/VC catalysts, higher ECSA for the Pt$\mathrm{Co} / \mathrm{VC}$ catalysts suggests better utilization efficiency due to smaller Pt-Co nanoparticles and better particle distribution [34-36].

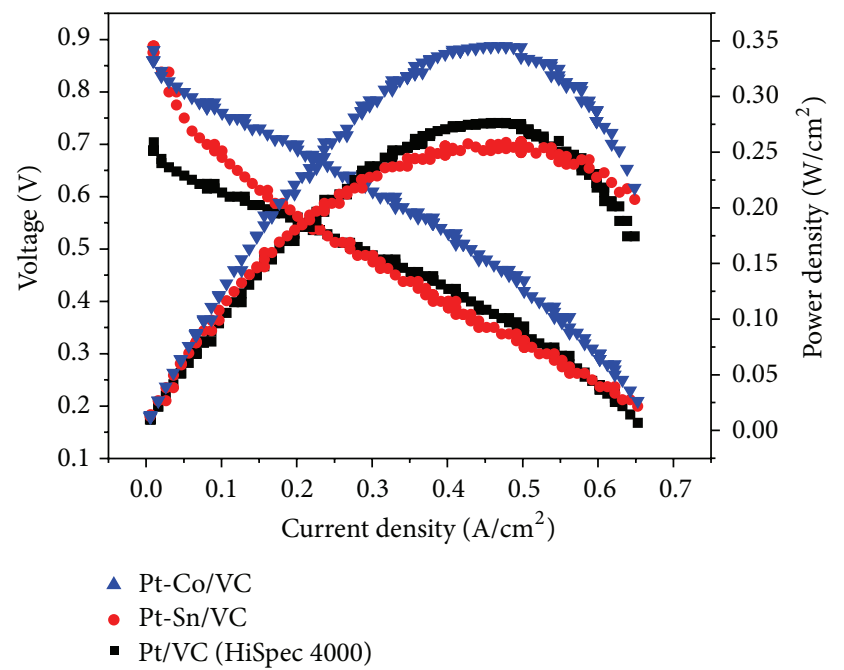

FIGURE 7: Polarization and power density plots at $60^{\circ} \mathrm{C}$ for PEMFCs using Pt-Co/VC, Pt-Sn/VC, and Pt/VC (HiSpec 4000) anode catalysts prepared by RIR. Test conditions: back pressure, $\mathrm{PO}_{2}=0 \mathrm{kPa}$, $\mathrm{PH}_{2}=0 \mathrm{kPa} ; \mathrm{O}_{2}$ and $\mathrm{H}_{2}$ gases flowing at 200 SCCM and 400 SCCM; the catalyst loading was $0.2 \mathrm{mg}$ of $\mathrm{Pt}$ at the cathode and $0.4 \mathrm{mg}$ of $\mathrm{Pt}-\mathrm{M}$ or Pt $/ \mathrm{cm}^{2}$ at the anode; $\mathrm{T}_{\text {cell }}=60^{\circ} \mathrm{C}$.

Figure 7 shows the polarization performance and power density curves of PEMFCs at $60^{\circ} \mathrm{C}$ using $\mathrm{Pt}-\mathrm{Co} / \mathrm{VC}$ and $\mathrm{Pt}-$ $\mathrm{Sn} / \mathrm{VC}$ electrocatalysts. The $\mathrm{H}_{2}$-fueled fuel cell polarization at low current density is electrochemical-activation controlled and mainly attributed to the sluggish HOR at the anode surface. The lowest loss in polarization voltage was observed for the $\mathrm{Pt}-\mathrm{Co} / \mathrm{VC}$ catalyst compared to the $\mathrm{Pt}-\mathrm{Sn} / \mathrm{VC}$ catalyst, 
indicating that the highest catalytic activity was toward the HOR. The maximum power density is $345 \mathrm{~mW} \mathrm{~cm}^{-2}$ for the $\mathrm{Pt}-\mathrm{Co} / \mathrm{VC}$ catalyst, which is much higher than the maximum power density observed for the Pt-Sn/VC $\left(275 \mathrm{~mW} \mathrm{~cm}^{-2}\right)$ and $\mathrm{Pt} / \mathrm{VC}\left(252 \mathrm{~mW} \mathrm{~cm}^{-2}\right)$ catalysts. Once more, this illustrates that the Pt-Co/VC catalyst exhibits better fuel cell performance compared to those other catalysts (HiSpec 4000, Pt$\mathrm{Sn} / \mathrm{VC}$ ), which is in full agreement with electron microscopy (HR-TEM, HR-SEM) data and the XRD data. The Pt-Co/VC catalysts exhibited a power density that was similar to the HiSpec $4000 \mathrm{Pt}$ (40 wt\%)/VC catalysts [34, 35], respectively. Surprisingly, the Pt-Co catalysts outperformed the state-ofthe-art commercial Pt/VC (HiSpec 4000), having half as much Pt loading. Higher HOR electrocatalytic activity and better fuel cell performance are attributable to its larger ECSA, which is closely related to the smaller nanoparticles and the greater uniform particle dispersion of the Pt-Co catalyst (one-step radiation-induced reaction) on the VCsupported electrocatalyst [35-37].

\section{Conclusions}

In this study, VC-supported electrocatalysts were synthesized by a one-step radiation-induced reaction process in aqueous solution at room temperature without reducing agents. The efficiency of the prepared electrocatalysts was evaluated. The following conclusions were drawn based on the experimental results. In spite of the low metallic contents of Pt-Co/VC electrocatalysts, there efficiencies for hydrogen oxidation reaction and power density were higher than those of the $\mathrm{Pt} / \mathrm{VC}$ and $\mathrm{Pt}-\mathrm{Sn} / \mathrm{VC}$ electrocatalysts. The resulting Pt$\mathrm{Co} / \mathrm{VC}$ electrocatalyst has demonstrated its possibility as a promising electrocatalyst in PEMFC.

\section{Conflict of Interests}

The authors declare that there is no conflict of interests regarding the publication of this paper.

\section{References}

[1] T. E. Springer, T. A. Zawodzinski, and S. Gottesfeld, "Polymer electrolyte fuel cell model," Journal of the Electrochemical Society, vol. 138, no. 8, pp. 2334-2342, 1991.

[2] R. L. Borup and N. E. Vanderborgh, "Design and testing criteria for bipolar plate materials for PEM fuel cell applications," in Materials Research Society Symposium Proceedings, vol. 393, pp. 151-155, April 1995.

[3] P. Adcock, Development of Cost Effective, High Performance PEM Fuel Cells for Automotive Applications, IQPC, London, UK, 1998.

[4] P. L. Hentall, J. Barry Lakeman, G. O. Mepsted, P. L. Adcock, and J. M. Moore, "New materials for polymer electrolyte membrane fuel cell current collectors," Journal of Power Sources, vol. 80, no. 1, pp. 235-241, 1999.

[5] H. I. Lee, C. H. Lee, T. Y. Oh, S. G. Choi, I. W. Park, and K. K. Baek, "Development of $1 \mathrm{~kW}$ class polymer electrolyte membrane fuel cell power generation system," Journal of Power Sources, vol. 107, no. 1, pp. 110-119, 2002.
[6] L. Xiong, A. M. Kannan, and A. Manthiram, "Pt-M ( $\mathrm{M}=\mathrm{Fe}$, $\mathrm{Co}, \mathrm{Ni}$ and $\mathrm{Cu}$ ) electrocatalysts synthesized by an aqueous route for proton exchange membrane fuel cells," Electrochemistry Communications, vol. 4, no. 11, pp. 898-903, 2002.

[7] T. Toda, H. Igarashi, H. Uchida, and M. Watanabe, "Enhancement of the electroreduction of oxygen on Pt alloys with $\mathrm{Fe}, \mathrm{Ni}$, and Co," Journal of the Electrochemical Society, vol. 146, no. 10, pp. 3750-3756, 1999.

[8] H. Yano, M. Kataoka, H. Yamashita, H. Uchida, and M. Watanabe, "Oxygen reduction activity of carbon-supported Pt$\mathrm{M}(\mathrm{M}=\mathrm{V}, \mathrm{Ni}, \mathrm{Cr}, \mathrm{Co}$, and $\mathrm{Fe})$ alloys prepared by nanocapsule method," Langmuir, vol. 23, no. 11, pp. 6438-6445, 2007.

[9] T. Tadaki, K. Kifune, Y. Kubota, and H. Yamaoka, "Stabilization of the gamma phase in Fe-Pt alloy nanoparticles with low Pt contents prepared by chemical synthesis method," Materials Science and Engineering A, vol. 438-440, pp. 407-410, 2006.

[10] D. L. Wood III, J. S. Yi, and T. V. Nguyen, "Effect of direct liquid water injection and interdigitated flow field on the performance of proton exchange membrane fuel cells," Electrochimica Acta, vol. 43, no. 24, pp. 3795-3809, 1998.

[11] J. S. Yi and T. Van Nguyen, "Multicomponent transport in porous electrodes of proton exchange membrane fuel cells using the interdigitated gas distributors," Journal of the Electrochemical Society, vol. 146, no. 1, pp. 38-45, 1999.

[12] A. Kumar and R. G. Reddy, "Effect of channel dimensions and shape in the flow-field distributor on the performance of polymer electrolyte membrane fuel cells," Journal of Power Sources, vol. 113, no. 1, pp. 11-18, 2003.

[13] E. Hontañón, M. J. Escudero, C. Bautista, P. L. García-Ybarra, and L. Daza, "Optimization of flow-field in polymer electrolyte membrane fuel cells using computational fluid dynamics techniques," Journal of Power Sources, vol. 86, no. 1, pp. 363-368, 2000.

[14] V. Gurau, F. Barbir, and H. Liu, "Analytical solution of a half-cell model for PEM fuel cells," Journal of the Electrochemical Society, vol. 147, no. 7, pp. 2468-2477, 2000.

[15] N. P. Lebedeva and G. J. M. Janssen, "On the preparation and stability of bimetallic $\mathrm{PtMo} / \mathrm{C}$ anodes for proton-exchange membrane fuel cells," Electrochimica Acta, vol. 51, no. 1, pp. 2940, 2005.

[16] B. Moreno, J. R. Jurado, and E. Chinarro, "Pt-Ru-Co catalysts for PEMFC synthesized by combustion," Catalysis Communications, vol. 11, no. 2, pp. 123-126, 2009.

[17] M. Mirdamadi-Esfahani, M. Mostafavi, B. Keita, L. Nadjo, P. Kooyman, and H. Remita, "Bimetallic Au-Pt nanoparticles synthesized by radiolysis: application in electro-catalysis," Gold Bulletin, vol. 43, no. 1, pp. 49-56, 2010.

[18] A. Henglein, "Physicochemical properties of small metal particles in solution: "Microelectrode" reactions, chemisorption, composite metal particles, and the atom-to-metal transition," The Journal of Physical Chemistry, vol. 97, no. 21, pp. 5457-5471, 1993.

[19] D. Lee, S. Hwang, and I. Lee, "A study on composite PtRu(1:1)PtSn(3:1) anode catalyst for PEMFC," Journal of Power Sources, vol. 145, no. 2, pp. 147-153, 2005.

[20] L. Ma, H. Zhang, Y. Liang et al., "A novel carbon supported $\mathrm{PtAuFe}$ as CO-tolerant anode catalyst for proton exchange membrane fuel cells," Catalysis Communications, vol. 8, no. 6, pp. 921-925, 2007.

[21] L. G. S. Pereira, V. A. Paganin, and E. A. Ticianelli, "Investigation of the $\mathrm{CO}$ tolerance mechanism at several Pt-based 
bimetallic anode electrocatalysts in a PEM fuel cell," Electrochimica Acta, vol. 54, no. 7, pp. 1992-1998, 2009.

[22] S.-H. Choi, M.-S. Choi, K.-P. Lee, and H.-D. Kang, "Preparation and characterization of CdS and CdS/polyacrylonitrile nanocomposites by $\gamma$-irradiation and emulsion polymerization," Journal of Applied Polymer Science, vol. 91, no. 4, pp. 23352342, 2004.

[23] Y.-O. Kang, S.-H. Choi, A. Gopalan, K.-P. Lee, H.-D. Kang, and Y. S. Song, "One-pot synthesis of a few nanocomposites with poly(N-vinylcarbazole) and CdS, Ag, Pd50-Ag50, and Pt50-Ru50 nanoparticles with $\gamma$ irradiation," Journal of Applied Polymer Science, vol. 100, no. 3, pp. 1809-1815, 2006.

[24] K.-D. Seo, S.-D. Oh, S.-H. Choi, S.-H. Kim, H. G. Park, and Y. P. Zhang, "Radiolytic loading of the Pt-Ru nanoparticles onto the porous carbons," Colloids and Surfaces A: Physicochemical and Engineering Aspects, vol. 313-314, pp. 393-397, 2008.

[25] S.-G. Ryu, S.-W. Kim, S.-D. Oh, S.-H. Choi, H. G. Park, and Y. P. Zhang, "Preparation of Pd-PS, Pd-PSB and Pd-PSC nanoparticles by $\gamma$-irradiation and their catalytic efficiency in Sonogashira coupling reaction," Colloids and Surfaces A: Physicochemical and Engineering Aspects, vol. 313-314, pp. 224229, 2008.

[26] S.-J. Kim, S.-D. Oh, S. Lee, and S.-H. Choi, "Radiolytic synthesis of $\mathrm{Pd}-\mathrm{M}(\mathrm{M}=\mathrm{Ag}, \mathrm{Ni}$, and $\mathrm{Cu}) / \mathrm{C}$ catalyst and their use in Suzuki-type and Heck-type reaction," Journal of Industrial and Engineering Chemistry, vol. 14, no. 4, pp. 449-456, 2008.

[27] S.-D. Oh, M.-R. Kim, S.-H. Choi et al., "Radiolytic synthesis of $\mathrm{Pd}-\mathrm{M}(\mathrm{M}=\mathrm{Ag}, \mathrm{Au}, \mathrm{Cu}, \mathrm{Ni}$ and $\mathrm{Pt})$ alloy nanoparticles and their use in reduction of 4-nitrophenol," Journal of Industrial and Engineering Chemistry, vol. 14, no. 5, pp. 687-692, 2008.

[28] S.-K. Kim, H.-D. Kwen, and S.-H. Choi, "Radiation-induced synthesis of vinyl copolymer based nanocomposites filled with reactive organic montmorillonite clay," Radiation Physics and Chemistry, vol. 81, no. 5, pp. 519-523, 2012.

[29] B. Fang, N. K. Chaudhari, M.-S. Kim, H. K. Jung, and J.-S. $\mathrm{Yu}$, "Homogeneous deposition of platinum nanoparticles on carbon black for proton exchange membrane fuel cell," Journal of the American Chemical Society, vol. 131, no. 42, pp. 1533015338, 2009.

[30] J. R. C. Salgado, E. Antolini, and E. R. Gonzalez, "Carbon supported Pt-Co alloys as methanol-resistant oxygen-reduction electrocatalysts for direct methanol fuel cells," Applied Catalysis B: Environmental, vol. 57, no. 4, pp. 283-290, 2005.

[31] J. Llorca, N. Homs, J. León, J. Sales, J. L. G. Fierro, and P. Ramirez De La Piscina, "Supported Pt-Sn catalysts highly selective for isobutane dehydrogenation: preparation, characterization and catalytic behavior," Applied Catalysis A: General, vol. 189, no. 1, pp. 77-86, 1999.

[32] A. K. Shukla, M. Neergat, P. Bera, V. Jayaram, and M. S. Hegde, "An XPS study on binary and ternary alloys of transition metals with platinized carbon and its bearing upon oxygen electroreduction in direct methanol fuel cells," Journal of Electroanalytical Chemistry, vol. 504, no. 1, pp. 111-119, 2001.

[33] Z. Liu, B. Guo, L. Hong, and T. H. Lim, "Microwave heated polyol synthesis of carbon-supported PtSn nanoparticles for methanol electrooxidation," Electrochemistry Communications, vol. 8, no. 1, pp. 83-90, 2006.

[34] E. V. Spinacé, M. Linardi, and A. O. Neto, "Co-catalytic effect of nickel in the electro-oxidation of ethanol on binary Pt-Sn electrocatalysts," Electrochemistry Communications, vol. 7, no. 4, pp. 365-369, 2005.
[35] Y. M. Tsou, L. Cao, and E. D. Castro, "Novel high performance platinum and alloy catalysts for PEMFC \& DMFC," Preprints of Papers-American Chemical Society, Division of Fuel Chemistry, vol. 49, no. 2, pp. 679-680, 2004.

[36] H. Chhina, S. Campbell, and O. Kesler, "High surface area synthesis, electrochemical activity, and stability of tungsten carbide supported Pt during oxygen reduction in proton exchange membrane fuel cells," Journal of Power Sources, vol. 179, no. 1, pp. 50-59, 2008.

[37] M. S. Saha, A. F. Gullá, R. J. Allen, and S. Mukerjee, "High performance polymer electrolyte fuel cells with ultra-low Pt loading electrodes prepared by dual ion-beam assisted deposition," Electrochimica Acta, vol. 51, no. 22, pp. 4680-4692, 2006. 

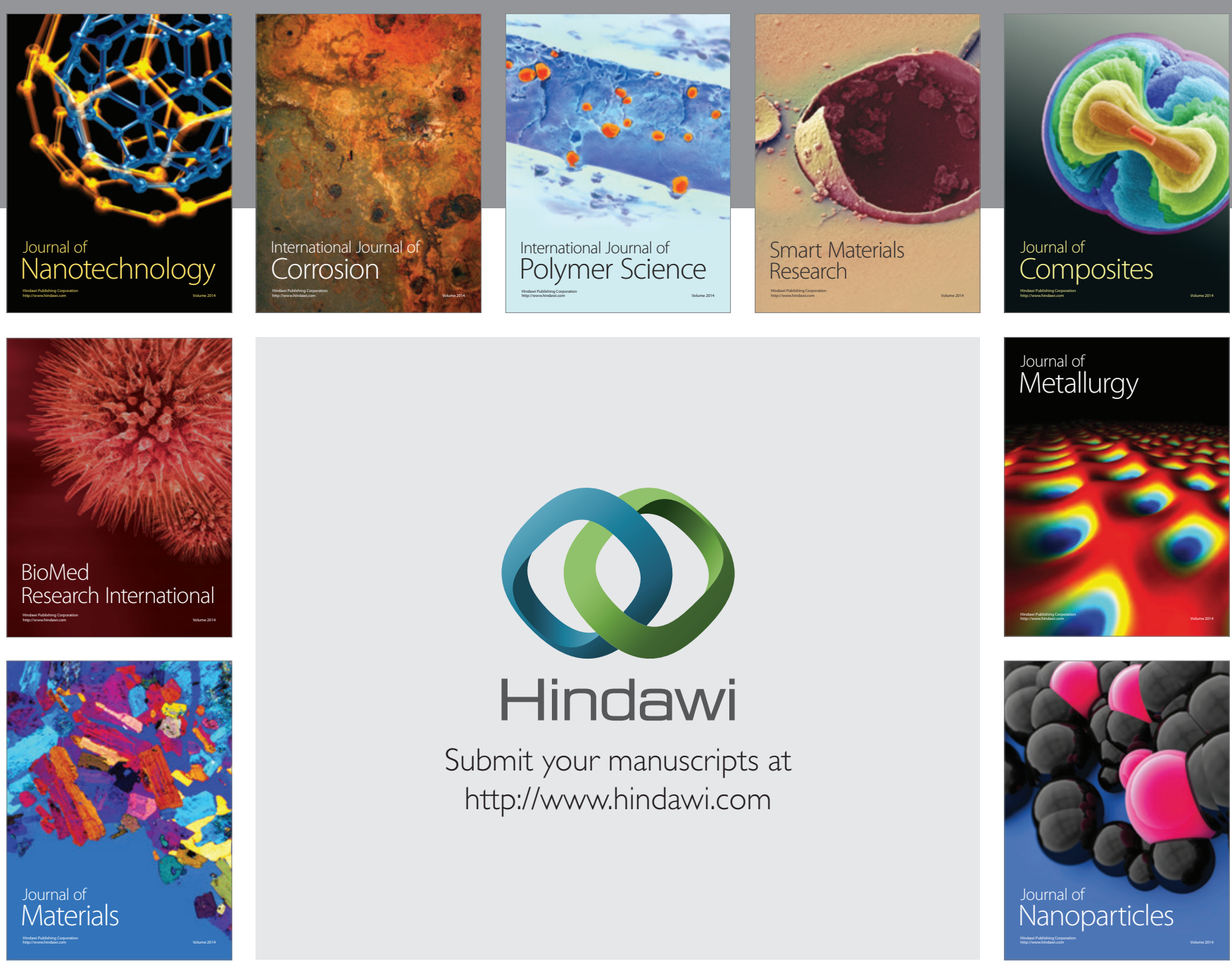

Submit your manuscripts at http://www.hindawi.com
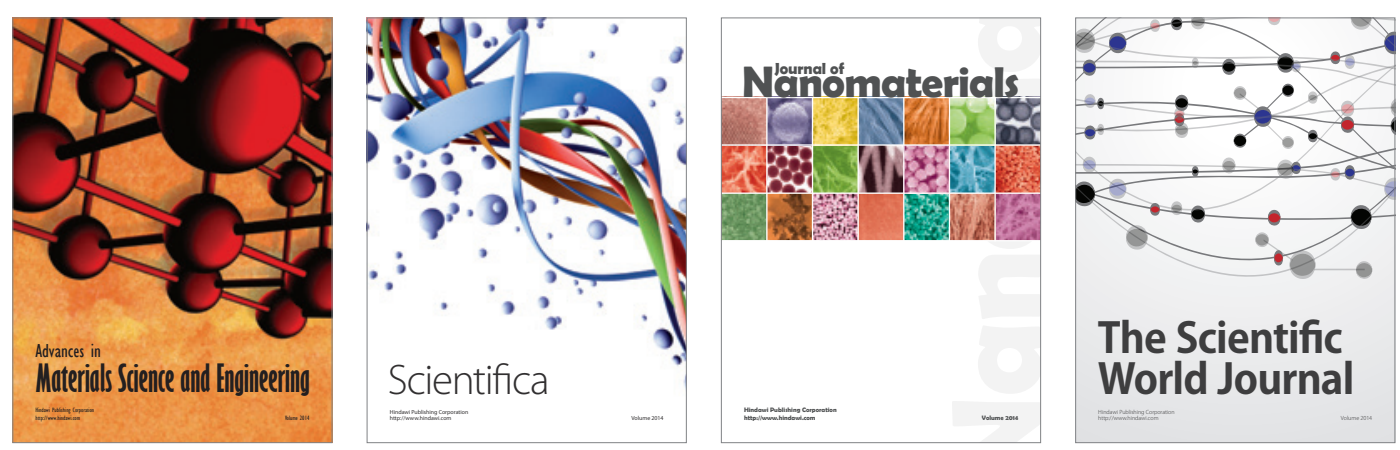

\section{The Scientific World Journal}
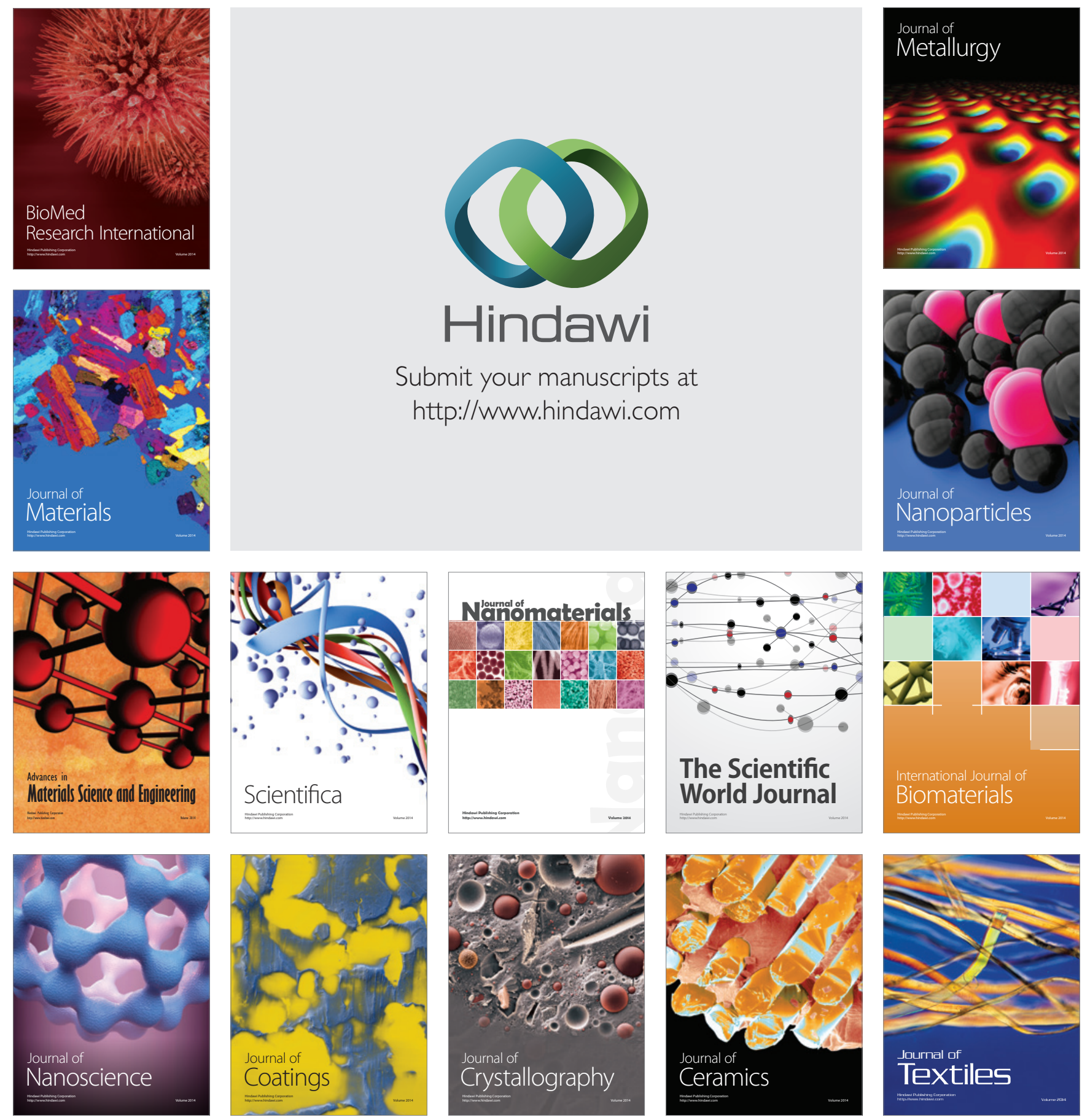